\title{
SOFTWARE EVOLUTION IN TURKEY
}

\author{
Alok Mishra, Ali Yazici, Semih Cetin
}

Professional pape

According to a recent Gartner report, Turkey is now to be considered in one of the world's outsourcing destinations since it has secured its place in the list of top 30 countries for Information Technology (IT), and offshore services. In the last decade, the country has made excellent progress in the software sector, and this is reflected in the rise of its exports to many countries. In this article, we present an overview of advancement of Turkey's software sector, including current trends in software process, testing, quality, and the adoption of agile methods along with techno parks and incentives provided by the government.

Keywords: software; software development; software engineering education information technology; Turkey

\section{Evolucija softvera u Turskoj}

Stručni članak

Prema zadnjem izvještaju Gartnera, Turska se sada treba uzeti u obzir jer si je osigurala mjesto među 30 vodećih zemalja na svijetu u području inormacijske tehnologije (IT) i inozemnih usluga. Tijekom zadnjeg desetljeća postignut je izvanredan napredak u području izrade kompjutorskih programa, a to je rezultiralo porastom izvoza u mnoge zemlje. U ovom radu dajemo pregled pomaka koji je Turska učinila u izradi programa, uključujući postojeće trendove, ispitivanja, kvalitetu i prihvaćanje agilnih metoda zajedno s tehno parkovima i poticajima koje daje vlada.

Ključne riječi: informacijska tehnologija u obrazovanju za izradu računrskih programa; računarski program; razvoj računrskih programa; Turska

\section{Introduction}

In recent years, Turkey has been increasingly positioning itself as a global provider of IT services, both in terms of application and infrastructure management and of end- user management [1].The software sector in this country has accelerated its efforts in various service areas, particularly in banking, insurance, defense, telecom, tourism, transport, logistics, and concluding contracting in almost all industrial sectors -especially in textiles, machinery, metal, automotive and vehicle parts [2]. This is possible due to a rise in awareness of corporate social responsibility, increasing importance in quality standards, and mandatory governmental implementations for applications, adoption of electronic services in both public and SMEs in all sectors, governmental incentives for IT start-ups, and increasing use of effective and efficient e-solutions in every aspect of life [2]. Moreover, Gartner has recently identified Turkey among the top 30 countries based on different attributes for IT offshore services between Europe, the Middle East, and Africa group (http://www.gartner.com/it/page.jsp?id=1500514). This article provides an insight into the software sector in Turkey in terms of current trends in software process, testing, quality, agile methods adoption along with techno parks and incentives provided by the government. Turkey's software market reached approximately US\$ 1,6 billion in 2009, up from $\$ 1,4$ billion in 2008, which was nearly $20 \%$ of IT. At the end of 2009 the growth rate of the Turkish software market was estimated at $7 \%$, and was expected to be $10 \%$ in 2010 . It is worth mentioning that the Turkish software market has experienced doubledigit growth recently [2].

\subsection{Software development organization}

IT companies in Turkey have been constructed and organized around Technology Development Zones (TGZs). Sixty-one such zones have been established by law, and as of August 2015, fourty-six of them have been active. These TGZs host the Techno Parks/Cities and around 3233 technology establishments. IT and Software Development companies have $58 \%$ of the shares in the technopark business. In addition, Technology Development Centers (TEKMER) under KOSGEB (Republic of Turkey Small and Medium Enterprises Development Organization), and Technology Free Zones (TEKSEBs) host IT companies. Altogether, in all these organizations established by law or decree, there are about 1600 software-development companies [3], $77 \%$ of which are located in the most populated cities- Istanbul, Ankara and Izmir.

There are approximately 35 large companies operating in the software market in Turkey. The product lines of these companies range from packaged programs to tailor-made software development for specific needs. Almost always, the public sector requires custom-built software for their specific purposes, while the private sector effectively employs a mix of customized products and software products. In Turkey, Milsoft Yazılım Teknolojileri A. Ş. is the first company to obtain SEI CMMI Level 5 rating. There are also various software companies (Havelsan, Ayesas, Meteksan, Koc System, Cybersoft etc.) which have CMMI Level 3 ratings [2]. It is also known that many Turkish software companies are on the way to obtain CMMI, SPICE:ISO 15504 standards, and getting ready to employ best practices of ITIL, and COBIT frameworks [2].

The following (Fig. 1) shows the sector-wise software development in Turkey.

\subsection{Government Incentives for software developers and R\&D staff}

In an attempt to encourage and support software developers various tools have been developed by state institutions, and offered to companies. Tab. 1 provides some of these major incentives offered to software developing companies. 


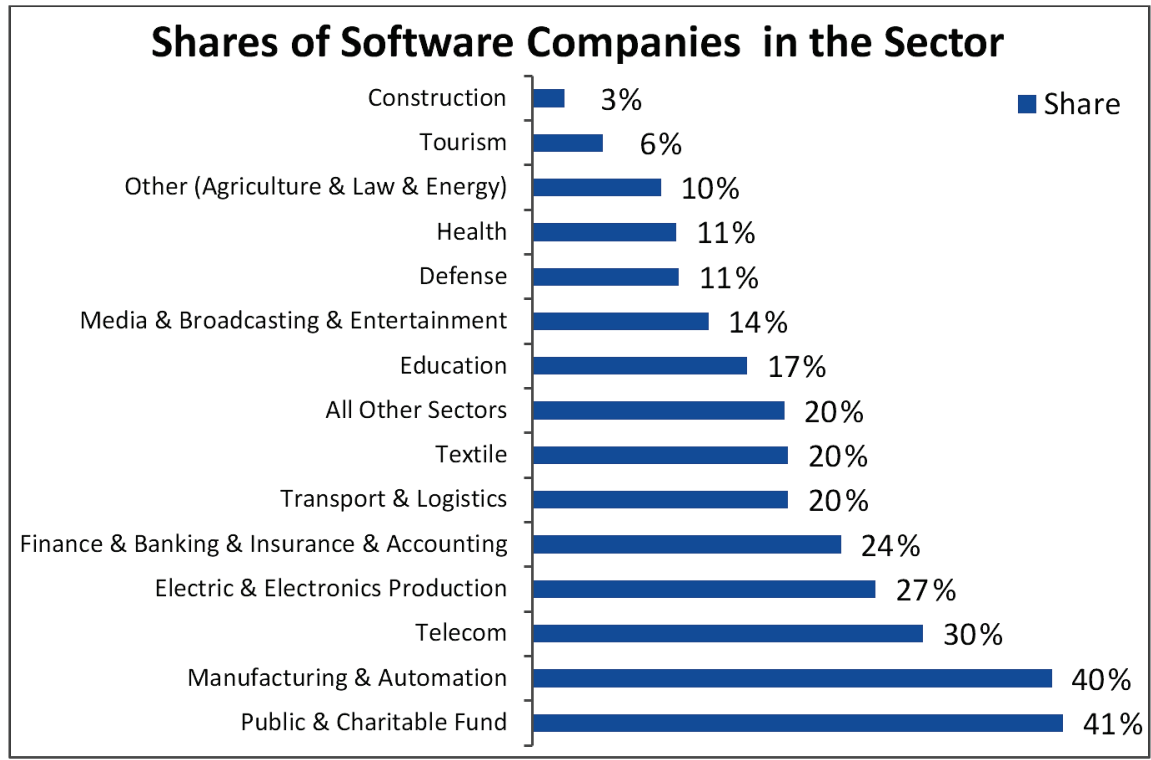

Figure 1 Sector-wise software development in Turkey (Adopted from [4])

Table 1 Software incentives (http://www.gib.gov.tr/fileadmin/beyannamerehberi/taxincentives.pdf and [5])

\begin{tabular}{|c|c|c|c|}
\hline Government incentives & \multicolumn{2}{|c|}{ Type of incentive } & Coverage \\
\hline \multirow{4}{*}{ Tax advantages for TDZs } & \multicolumn{2}{|c|}{$\begin{array}{l}\text { Income and Corporate Tax Exemption } \\
\text { (valid until } 31 \text { December 2013) }\end{array}$} & $\begin{array}{l}\text { Profits generated in TDZs resulting from } \\
\text { software and R\&D-based product software, on } \\
\text { activities }\end{array}$ \\
\hline & \multicolumn{2}{|c|}{$\begin{array}{l}\text { Income Tax Withholding Exemption } \\
\text { (valid until } 31 \text { December 2013) }\end{array}$} & $\begin{array}{l}\text { Wages and salaries of researchers and R\&D } \\
\text { personnel employed in the zone for their } \\
\text { research, software, and R\&D work }\end{array}$ \\
\hline & \multicolumn{2}{|c|}{ Exemption from Tax, Duties and Fees } & $\begin{array}{l}\text { Managing companies of TDZs in the } \\
\text { transactions concerning the implementation of } \\
\text { the TDZ law }\end{array}$ \\
\hline & \multicolumn{2}{|c|}{$\begin{array}{l}\text { Value Added Tax (VAT) Exemption } \\
\text { (valid until } 31 \text { December 2013) }\end{array}$} & $\begin{array}{l}\text { Delivery and services which are rendered and } \\
\text { manufactured in the TDZs }\end{array}$ \\
\hline \multirow[b]{2}{*}{$\begin{array}{l}\text { Direct support through } \\
\text { projects }\end{array}$} & $\begin{array}{l}\text { Funds for R\&D project } \\
\text { activities by the Turkish } \\
\text { Scientific and Technical } \\
\text { Research Council - } \\
\text { TÜBİTAK } \\
\text { (http://www.tubitak.gov.tr/en/f } \\
\text { unds/) }\end{array}$ & \begin{tabular}{|ll} 
1. & Funds for \\
& Academics \\
2. & Funds for \\
Business/Industry \\
3. & Scientific Meetings \\
Grant Program
\end{tabular} & All expenditures related to the project/program \\
\hline & $\begin{array}{l}\text { Capital support by the Turkish } \\
\text { Technology Development } \\
\text { Foundation - TTGV }\end{array}$ & \begin{tabular}{|ll} 
1. & Technology \\
& Development \\
& Project Support \\
2. & Commercialization \\
& Project Supports \\
3. & Advanced \\
& Technology Projects \\
& Support Program \\
& (ITEP)
\end{tabular} & Maximum $50 \%$ of the project's budget \\
\hline Indirect incentives & \multicolumn{2}{|c|}{$\begin{array}{l}\text { - Support for expenditures of patents, useful model } \\
\text { certificates - The Turkish Patent Institute } \\
\text { TÜBİTAK (Patent Application Promotion and } \\
\text { Funding Program) } \\
\text { (http://www.tubitak.gov.tr/en/funds/) }\end{array}$} & $\begin{array}{l}\text { Expenditures for patents and useful model } \\
\text { certificates for an invention which is created in } \\
\text { the projects realized by the people living in } \\
\text { Turkey }\end{array}$ \\
\hline
\end{tabular}

\section{Turkish software testing \& quality}

The Turkish Testing Board (TTB) has recently introduced the $2012 \div 2013$ edition of the Turkey Software Quality Report (TSQR). The edition was distributed nationwide as well as in more than 70 countries through its International Software Testing Qualifications Board (ISTQB) members. This report aims to show the significance given to software quality in Turkey, and to contribute positively to the image of IT industry throughout the world. One can easily see that when compared to $2010 \div 2011 \mathrm{TSQR}$ results, the maturity level of software testing has improved in 2012 [6]. Most of companies have managed to establish dedicated test teams, the number of testers responsible for testing has also increased against developers, business analysts, and end users. However, the time allocated for software testing during IT projects is still found to be unsatisfactory [6], the main challenge ahead of software testers is the lack of domain knowledge. In order to 
overcome this issue, more companies are planning to assign system analyst teams for software testing in their organizations. Within five years, end-users and developers are to be eradicated in this test responsibility graph - even in mid-sized companies. End users are to be involved in UATs (User Acceptance Testing), and developers will be solely responsible for Unit Tests. Almost $65 \%$ of the survey respondents in the TSQR have also indicated that the time allocated for software testing is less than $30 \%$ of their total project timeline [6]. The latencies in analysis, design, and development stages are compensated by reducing the time likely to be for testing. In this respect, these results in customer dissatisfaction and a large number of defects found in products, possibly lead to concerns over quality in the delivered software [6]. This may lead to quality issues in delivered software to customers.

\section{Agile software development}

In the last few years, the Agile Software Development paradigm has become increasingly popular since it can bring about lower costs, better productivity, quality and business satisfaction [8]. Recently,small-tomedium IT organizations, especially those involved in custom-built software have been anticipating agile software development techniques, such as Extreme Programming (XP) and Scrum. Furthermore, with the adoption of agile software development methodologies like Test-Driven Development, the time allocated for testing activities has increased. According to recent survey results, the top three challenges with test automation are test data preparation, lack of test design techniques, and integration into current systems [6]. In test automation frameworks, the most challenging criteria to meet are maintainability and reusability. As a simple example, the test scripts prepared for one build cannot be utilized in the testing of the next builds [6]. Specifically in agile projects, where regression cycles are frequent, this makes test automation useless. However, the major problem is more strategic, - and that is the perception of test automation as a magician in testing of software [6].

\section{Software project process, success rate and criteria}

In a recent survey, 400 people working in IT departments at 50 companies were surveyed [7]. $94 \%$ of the respondents had more than 3 years of experience in software development, and $49 \%$ of them were managers involved in software development. It has been realized that $50 \%$ of the respondents are currently using waterfall and derivatives but only $33 \%$ of the respondents are planning to continue to use this while $64 \%$ intends to use agile processes in the near future. $53 \%$ are currently using traditional development practices. However, only $37 \%$ are planning to continue using traditional development practices. According to $45 \%$ of the respondents, project success rate is over $70 \%$, it is expected to improve by the increasing use of agile processes as $64 \%$ of the respondents who claimed that their project success rate was over $70 \%$ employ agile processes and prefer agility [7]. In terms of project success, $34 \%$ of the respondents mentioned that high quality and functionality create value in the product, consequently, customer satisfaction is more important than abiding by time and budget plans. $88 \%$ of the respondents attached importance to customer involvement, efficient adaptation to change, and achievement of high quality [7]. In terms of strategies for success, most of the respondents found that by increasing significance of time to market, detailed upfront analysis as well as detailed upfront planning of time and budget are expected to lose their term and suggested that by adopting agility like high customer involvement, incremental delivery of sofware, adapting the plans immediately according to change and high quality are going to be achieved [7].

\section{Techno Parks}

All techno parks/cities in Turkey are located in the 46 active TGZs hosting about 3233 technology establishments, providing job opportunities to more than 32000 employees. The total amount of exports is about 2 billion USDs as of 2015. About 1875 (58\%) of these companies are in the IT and Software Research and Development sector.

Table 2 Techno Park summary data [9]

\begin{tabular}{|l|c|}
\hline Number of companies & 3233 \\
\hline Number of employees & 32196 \\
\hline Number of completed projects & 16194 \\
\hline Number of ongoing projects & 7297 \\
\hline Number of foreign investors & 141 \\
\hline Exports & 2 Billion US Dollars \\
\hline Number of patents & 446 \\
\hline $\begin{array}{l}\text { Number of patent applications } \\
\text { in process }\end{array}$ & 714 \\
\hline
\end{tabular}

All of these techno parks are usually affiliated with universities and physically located within university campuses with the advantage of hiring highly qualified R\&D technical (faculty members) and research support staff (research assistants) from the related academic departments.

In Turkey, Techno parks are mostly IT focused, and the oldest one, technopark named METUTECH and established as a TGZ in 2001, is located at the Middle East Technical University, hosting over 262 companies, $75 \%$ of which are SMEs. The existing company profile of METUTECH is based on software development and IT $(55 \%)$, defense $(21 \%)$, and electronics $(10 \%)$ industry. This profile is almost the same as the other techno parks in the country. The incubation center of METUTechnopolis serves 38 micro-sized companies; most of which are spin-offs from the Middle East Technical University. In the last four years, about ten million euros have been spent for completing the infrastructure and facilities of the science park. Today, METUTECH operates in an area of about 60000 square meters. It provides several free services to its clients on different subjects, like Intellectual Property Rights (IPR), licensing, patent consulting, and legal issues such as contract management, international marketing, and financing. Presently, METUTECH manages 30 national and international projects ( 4 of which are EU projects). The 
company has a wide range of knowledge and practice in project management, from scheduling to book-keeping, coordination, and control. Most of these projects have partners from universities to industry and non-profit organizations. Futhermore, these projects are focused around ICT (software development), Electronics (defense), Telecommunications, Energy, Automotive, Biotechnology, Health Care \& Medicine, Advanced Engineering (aerospace, defense, advanced materials), and Environment.

\subsection{Software development export market}

Recently, Turkish software companies have directed their expertise to exports to almost 70 countries. Realizing efforts to improve the institutionalization, quality and competitiveness of the software sector, it is estimated that software export volume will reach US\$1 billion per annum by 2015 (http://www.yasad.org.tr/en). EU countries, North Africa, the Middle East, the Caucasus and Central Asian countries are among the major software export markets of Turkey. According to the Association of Software Industrialists (YASAD), Turkish software market, which had been realized as 800 million dollars in the year before, reached 1,2 billion dollars in 2012 (http://www.tim.org.tr/en/in-the-spotlight-turkey-is-oncourse-to-become-an-etiger-in-software.html). In terms of past years, in 2009 the total value of registered software export exceeded USD12,9 million. While it was similar in 2008, in 2007 it was USD 14,3 million [2]. The main export markets for Turkish made software are Germany, the USA, United Arab Emirates, Libya, the UK, Azerbaijan, Switzerland, Romania, Turkmenistan and Greece [2]. The Turkish ICT market grew exponentially by 14 percent CAGR between 2002 and 2010, reaching USD 28,5 billion in 2010, and was expected to exceed USD 30 billion in 2011 according to interpromedya. Further 28 out of 500 ICT companies in Europe, the Middle East, and Africa (EMEA region) were Turkish companies in 2010 (Deloitte Technology Fast 500 EMEA) US/sectors/Pages/ICT.aspx).

\subsection{Turkey's software export market}

The software growth and export of Turkey can be seen in Fig. 2 and Tab. 3 respectively.

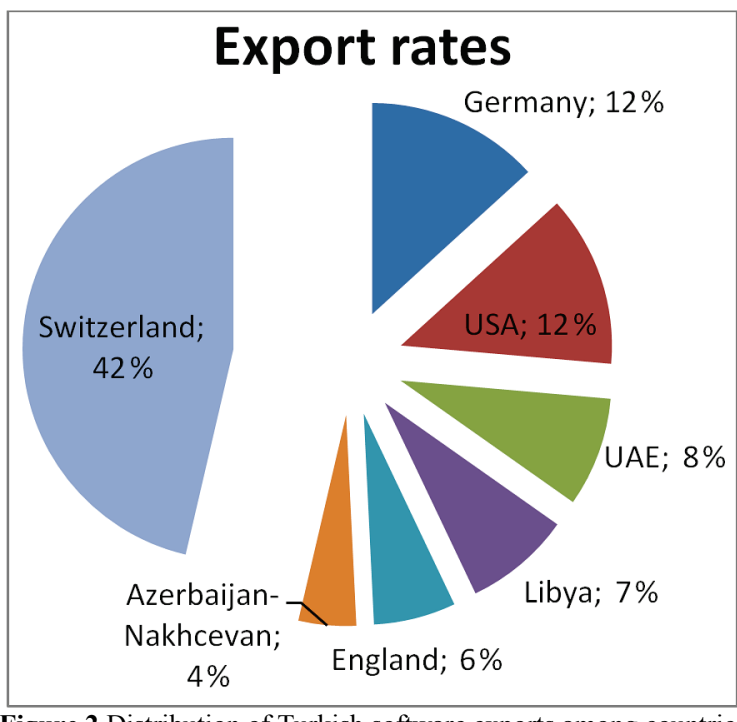

Figure 2 Distribution of Turkish software exports among countries (adopted from [4])

Table 3 Turkey's Software Export by Country (US \$) (adopted from [2])

\begin{tabular}{|l|r|r|r|}
\hline \multicolumn{1}{|c|}{ Country } & \multicolumn{1}{c|}{$\mathbf{2 0 0 7}$} & \multicolumn{1}{c|}{$\mathbf{2 0 0 8}$} & \multicolumn{1}{c|}{$\mathbf{2 0 0 9}$} \\
\hline Germany & 3735689 & 2431523 & 1549775 \\
\hline The USA & 1317092 & 277638 & 1541124 \\
\hline UAE & 225489 & 59190 & 1098833 \\
\hline Libya & 37562 & 646468 & 981631 \\
\hline The UK & 760873 & 1046493 & 966618 \\
\hline Azerbaijan & 157914 & 594064 & 744252 \\
\hline Switzerland & 9875 & 374527 & 524284 \\
\hline Tubitak Free Zone & 98476 & 153848 & 520032 \\
\hline İstanbul Leather Free Zone & 275717 & 207051 & 503599 \\
\hline Romania & 190386 & 521150 & 501440 \\
\hline Turkmenistan & 14490 & 99174 & 480114 \\
\hline İstanbul AHL Free Zone & 400055 & 372148 & 410034 \\
\hline Greece & 1238351 & 904060 & 355058 \\
\hline Israel & 39306 & 117254 & 343888 \\
\hline Turkish Republic of North Cyprus & 317171 & 210815 & 315658 \\
\hline Bulgaria & 37168 & 2006 & 313909 \\
\hline Albania & 70313 & 222317 & 268425 \\
\hline The Netherlands & 596128 & 482660 & 256446 \\
\hline Kazakhstan & 917285 & 1036474 & 154784 \\
\hline Ege Free Zone & 128899 & 137545 & 141187 \\
\hline Others & $\mathbf{1 4 3 2 2 1 2}$ & $\mathbf{1 2 ~ 8 8 9 9 8 4}$ & $\mathbf{1 2 9 0 1 3 8 1}$ \\
\hline TOTAL & & & 930290 \\
\hline
\end{tabular}

\subsection{Turkey as an IT outsourcing country}

It is perceived that the Turkish software sector seems to be competitive on a global scale with successful applications in different business domains. However, it is still a reality that Turkey has not yet been able to take a key role in spite of its current proven potential. In order to compare the software-development capability of different 
countries, the so-called Global Services Location Index (GSLI) analyzes and ranks the top 50 countries worldwide as the best destinations for outsourcing activities [10]. Based on this study, it appears that Turkey is the $44^{\text {th }}$ in the top 50 considering the overall score. Turkey registers the second largest increase in ranking this year (2016), vaulting 18 positions up the Index at 21 . A close analysis of these three categories is important to provide a better insight into Turkey's standing on the global scale and to identify the points for improvement. It appears that the top three outsourcing countries - China, India and Malaysia - have a very high financial attractiveness and high People Skills Index score. Turkey seems to be somewhere in the middle, having an average Financial Attractiveness Index value and still a competent People Skills Index value.

A closer look at the global software engineering capability of Turkey ends up with the following conclusion. On one hand, Turkey's software sector is growing internally, and a similar trend has been experienced in the software exports over the recent years. On the other hand, the values from a global perspective indicate that Turkey is not playing an important role yet as a software-development country. Here, the role of Turkey can be distinguished as either an outsourcing nation, the active initiator of outsourcing, or as a host nation for developing software that was outsourced by foreign countries. In fact, based on the existing literature, we can state that both roles have their own advantages, including relieving resource shortages, cost savings, staffing flexibility, reducing unemployment, and leveraging expertise. In contrast to the current potential workforce and economic growth of Turkey in the recent years, the minor role of the Turkish software sector in the global arena indicates a clear missed chance, both for Turkey itself and for supplier countries. With a population of more than 78 million, Turkey has a wide range of business expertise in diverse sectors such as automotive, textile, finance, tourism, defense, healthcare, agriculture, telecommunications, and machinery. Several of these sectors are quite successful and are currently visible on the global market. The pioneering organizations in these sectors have also created an IT demand for their products. Despite the positive developments in these sectors and its impact on the IT and software sector, more systematic approaches and strategies are required to boost the software industry in Turkey at a global level [11].

\subsection{Human capital and software engineering education in Turkey}

Turkey is a country with around 77 million inhabitants. Of these, approximately $65 \%$ are younger than 34 years. With an average age of 29 , it has a very young population, and it is therefore not surprising that nearly 1 million new students register at Universities, and 400000 graduates enter the Turkish labor market annually. Turkey provides a very wide range of highly skilled workers to industries. A clear trend is that an increasing number of graduates and students have a good knowledge of English and that technical education and computer science are becoming increasingly popular. Many Turkish youngsters spend a number of years abroad to pursue Masters and $\mathrm{PhD}$ courses before returning, and receive a good international orientation. The Turkish government also supports this move by providing a number of scholarships for Masters, doctoral and postdoctoral studies [1].

Finally, it must be noted that universities contribute a significant role in software development, IT and related research and development. It is the responsibility of Software engineering education to prepare $\mathrm{SE}$ professionals by providing them with the skills to meet the expectations of the software industry. SE curriculum should correspond to the industry needs, and only then can Universities produce highly skilled professionals, who can meet the needs of software industry [12]. Universities in Turkey have initiated Software Engineering (SE) undergraduate programmes only in the last decade. Before this, the software industry relied heavily on the graduates of the Computer Engineering and other related programmes. So far, in Turkey, 11 (10 foundation/private and one government) universities out of 168 offer SE undergraduate programmes with a total number of 921 intakes in the $2011 \div 2012$ Academic Year where the acceptance (by exam) rate was only about 50 $\%$. The intake in the $2012 \div 2013$ Academic Year was 816, and the acceptance rate became about $75 \%$. On the one hand, the software industry in Turkey is in great need of qualified software engineers.On the other hand, the sense of determination among the candidates is surprisingly low. This may be attributed to the low popularity of the field in the eyes of public compared to Computer Engineering and the high tuition fees at the foundation universities [13].

\section{Software development - Turkey and developed countries}

As the information and communication technology (ICT) sector continues to rise in the world and in Turkey, software is one of the fastest growing sectors. Turkish ICT sector has performed robust growth in recent years exceeding USD 30 billion by 2013 and is expected to reach USD 160 billion by 2023 [14]. In recent surveys, both large corporations and SMEs pointed their plan to increase short-term spending on IT. While the enterprise resource planning (ERP) segment continues to lead the enterprise application software (EAS) market, there is a growing interest for customer relationship management, human resource management, business intelligence, business-to-business, business-to-consumer, and software as a service. Despite the difficulties of finding accurate data, the Turkish software and services segments are estimated to have a size of approximately USD 2 billion, according to the Software Industrialists Association (YASAD). The Turkish software and services sector's volume is slightly above $0,3 \%$ of GDP, which is lower by the $2 \div 3 \%$ levels observed in many developed and developing countries [15].The ICT sector is directly responsible for $5 \%$ of European GDP, with a market value of $€ 660$ billion annually, but it contributes far more to overall productivity growth $(20 \%$ directly from the ICT sector and $30 \%$ from ICT investments). This is because of the high levels of dynamism and innovation inherent in the sector, and the enabling role the sector 
contributes in changing how other sectors do business [16]. In developed countries, various initiatives have been launched to improve the financing of software enterprises. For example, Enterprise Ireland introduced a venture capital program for supporting software funds, development-oriented funds, high-tech funds and business angels [17]. In 2010, 15 of the world's top 25 software firms were based in the USA, and 63 were in the top 100 software firms. However, the trend is that software companies from other countries are gaining ground. In 2008, the USA had as many as 74 entries on the list. In 2010, Japan saw 10 entries in the top 100, France six and the United Kingdom four. Only a few companies from developing economies feature in the top 100 list and none are included among the top 25 . There are, however, signs of fast growth among enterprises in Brazil, China, the Russian Federation and the Republic of Korea [17]. For example, according to data from the European Information Technology Observatory (EITO) [18], between 2008 and 2012 software markets grew by about $40 \%$ or more in China, India, the Russian Federation and in Latin America and the Caribbean, whereas the equivalent growth rates in North America and Europe were only about $15 \%$. Furthermore, IT services grew faster outside developed countries, especially in India and China [18].

\section{Conclusion}

Software evolution has moved towards new heights in last decade due to encouragement by government and their agencies. Due to incentive in tax provision and subsidies many organizations are opening software engineering research and development wing in their organizations. Tax advantages for TDZs, direct project support through TÜBİTAK and TTGV and indirect incentives in patents, certifications also boosted in this direction. Agile methods and use of different tools are becoming popular in software development towards productivity. In recent years many software organizations received CMMI level 3 to level 5 certifications. Thus it shows that software companies are moving towards mature process and quality software development for their clients. Due to these efforts Turkey software export is increasing. Still Turkey has to work in sustained manner towards higher rank as IT outsourcing country. The potential socioeconomic benefits of software in an emerging economy, such as Turkey, are enormous. Egovernment, e-business, e-health and military software are major areas of the software sectors domain. The establishment of Technoparks around major universities, and the increased number of government incentives along with improved Internet services have facilitated this growth process in software sector. In the last decade many Universities have started undergraduate and graduate programs in software engineering to cater manpower for growing demand of software engineers. This will also help in accomplishing success in software projects in terms of adoption of best processes towards higher quality on schedule and within budget. Better collaboration between the software industry and higher education departments can lead to synergies for both in accomplishing their objectives. If issues and challenges are identified in a timely manner, then the Turkish software sector is poised to achieve an important position at the global stage and also contribute towards its social and economic development.

\section{References}

[1] Software Development via Nearshoring The Turkish Way, URL: $\quad$ http://www.triodor.eu/Uploaded Files/762 TriodorNearshoringEnglish.pdf. (23.07.2012)

[2] Turkoglu, Y. Software Sector in Turkey, IGEME Export Promotion Center of Turkey, (2010).

[3] Sokmen, N. Competency Level of Turkish Software Developers: Development of companies and the Sector (in Turkish). // TUBITAK-BILGEM Publications.1, (2010).

[4] Gunes, D. U. Software Industry in Turkey (in Turkish). // YASAD. (2011) URL: http://yasad.org.tr/UserFiles/File/ YASAD_Presentation_v4.1\%2012_TR.pdf(July 11, 2012).

[5] Tirpanceker, G. Software Sector in Turkey and Values Added by Software (in Turkish). / Workshop on Software Sector in Turkey, Institute of Strategic Thinking, Ankara, Turkey, 2011. URL: http://www.sde.org.tr/userfiles/file/ Gulara Tirpanceker_SDE 2011Aral\%C4\%B1k-2.pdf. (11.07.2011)

[6] Turkey Software Quality Report 2012 - 2013. URL: http://www.turkishtestingboard.org/Turkey_Software_Qual ity_Report_2012-2013.pdf. (25.07.2012)

[7] Software Productivity Report 2012. URL: http://www.agileturkey.org/Pdf/software_productivity_repo rt.pdf. (20.07.2012)

[8] Mishra, D.; Mishra, A. Complex software project development: agile methods adoption. // J. Softw. Maint Evol. 23, 8(2011), pp. 549-564. DOI: 10.1002/smr.528

[9] Technology Development Regions Association: http://www.tgbd.org.tr/en.

[10] Kearney, A. T. The Shifting Geography of Offshoring, 2009.

[11] Tekinerdogan, B.; Cetin, S. Introducing Global Software Development in Turkey - Why and How? / International Conference on Global Software Engineering (ICGSE), 2012. DOI: 10.1109/icgse.2012.17

[12] Mishra, A.; Mishra, D. Industry Oriented Advanced Software Engineering Education Curriculum. // Croatian Journal of Education. 14, 3(2012), pp. 595-624.

[13] Mishra, A.; Yazici, A. An Assessment of the Software Engineering Curriculum in Turkish Universities: IEEE/ACM Guidelines Perspective. // Croatian Journal of Education. 13, 1(2011), pp. 188-219.

[14] Kaymaz, N. Turkish ICT Sector 2015. URL: http://www.slideshare.net/necmettinkaymaz/turkish-ictsector. (19.08.2015)

[15] Alican. F. The Turkish Software Sector at Turning Point 2013. URL: http://blog.fuatalican.com/the-turkish-softwaresector-at-a-turning-point.html. (19.08.2015)

[16] Information Economy Report (2012) The Software Industry and Developing Countries, UNCTAD, UN Report. URL:http://unctad.org/en/pages/PublicationWebflyer.aspx? publicationid=271. (14.08.2015).

[17] Information Technology Sector Report Europe Region 2011. URL: http://exportvirginia.org/global network/ IT\%20REPORT\%20-\%20EUROPE\%20JULY\%202011.pdf. (19.08.2015)

[18] EITO (2011) European Information Technology Observatory 2011. URL: http://www.eito.com/EITO-2011. (19.08.2015) 


\section{Authors' addresses}

Alok Mishra, Corresponding author

Software Engineering Department,

Atilim University, Ankara, Turkey

E-mail: alok.mishra@atilim.edu.tr

\section{Ali Yazici}

Software Engineering Department,

Atilim University, Ankara, Turkey

E-mail: ali.yazici@atilim.edu.tr

\section{Semih Cetin}

Managing Partner,

Cybersoft Information Technologies Limited Company,

İstanbul, Turkey

E-mail: semih.cetin@cybersoft.com.tr 